\title{
Protection of hop with biological preparations
}

\author{
Venger $0 .^{1}$, Fedorchuk N. ${ }^{2}$, Drankivskyi V. ${ }^{3}$ \\ 1, 2 Institute of Agriculture of Polissya, NAAS, Zhytomyr, Kyivske Shose Str., 131, 10007, Ukraine, ${ }^{3} \mathrm{Head}$ of \\ the Department of forecasting, phytosanitary diagnosis and risk analysis, phytosanitary, and safety \\ management, Gagarin Str., 55, Zhytomyr, 10002, Ukraine; e-mail: 1, ${ }^{2}$ venger_o@ukr.net, \\ ${ }^{3}$ drankowsky@ukr.net
}

The purpose. To study an opportunity of application of biological fungicide Avatar-1, r. Zashchita against the basic illnesses in technique of cultivation of hop. Methods. Field experiment was spent using S.A. Tribel's technique (2001). After studying biofungicide Avatar-1, r. Zashchita within 3 years they have chosen the most efficient concentrations of working solution -10 and $20 \mathrm{ml} / 10$ I of water. They soaked ( 3 hours) cuttings of hop in the given water solutions before planting in soil. Fructifying plants they sprayed against pseudoperonosporosis with the help of tractor fan sprayer OPV-2000. In reference variant they used fungicide of systemic action Ridomil Gold MZ, inc. In control variant they used pure water. Presence of acids in hop cones was determined according to «GOST 4099:2009 Hop. Rules of sampling and test methods». Results. It is established that soaking of cuttings of hop in water solution of biofungicide Avatar- $1, \mathrm{r}$. Zashchita before planting in field provides their survival up to $70 \%$ (on $6,5 \%$ more than in the control), and positively influences process of formation and exit of standard seedlings, enables twice to lower amount of ear shoots on sprouts of hop. Efficiency of protection of fructifying plants of hop against false mealy dew in the way of land spraying makes $74,2-74,4 \%$; productivity of cones, in comparison with control, increases on 1,9-2,2 c/hectare, and contents of -acids - on 1,1\%. Conclusions. Application of biofungicide Avatar-1, r. Zashchita in the system of protection of hop enables effectively to constrain development and distribution of the most dangerous illness of hop (pseudoperonosporosis) in the beginning of vegetation and to receive standard planting material or the planned productivity of hop cones of appropriate quality.

Key words: biological preparation, cuttings of hop, degree of affection, distribution, pseudoperonosporosis, root rot, productivity, content of a-acids.

DOI: https://doi.org/10.31073/agrovisnyk201903-05

The modern ecological state of agroecosystems of Ukraine is mainly influenced by anthropogenic factors, in particular the use of highly toxic pesticides for the protection of agricultural plants against pests, diseases and weeds. It has been established that pesticides become factors for the selection of persistent races and the population of pests or phytopathogens, their massive use pollutes agrocenoses and water resources, causes harm to people and the environment [1].

Many years of experience in many countries of the world show that preventing the negative effects of the use of chemical pest and disease protection products is possible only with the use of substances of natural origin [2].

Analysis of recent research and publications. Among the many viruses, bacteria, and fungi are those that are able to drastically reduce and limit the development of various harmful objects. Created on the basis of their biological products, along with direct protective effect, contribute to the improvement of agrocenosis, improve their phytosanitary status, reduce the pesticide load, therefore their use is a significant alternative to chemical protection [3]. Ukraine produces a new high-performance microelement drug, Avatar-1, $p$. Protection of production of LLC "NVK AVATAR". This is a new generation biofungicide with growth stimulating properties used to treat seeds and vegetative plants. High effectiveness of the drug is due to the complex action of organic compounds of sulfur, copper and iodine with citric acid, enhanced synergistic effects of aluminum ions, nickel, vanadium and cobalt (active substances) [4]. The trace elements that are part of the drug, show their systemic and contact toxic effects on phytopathogens due to properties that are inherent only to them.

Avatar-1, p. Protection also provides fungicidal effects on pathogens, it activates plant growth processes, improves mineral nutrition, purifies the soil from residues of pesticides, restores and activates the useful 
microflora of life $[4,5]$. The great advantage of the drug is that it is completely safe for humans, warmblooded animals, fish, bees, and plants [6].

Reception of high and stable harvests of hops depends to a great extent on the quality of the planting material [7], therefore the provision of hops producers for high quality seedlings is of particular importance [8]. The purpose is to study the possibility of using the biological fungicide, Avatar-1, p. Protect against major diseases in the technology of growing hop.

Materials and methods of research. In the Department of Plant Protection of the Institute of Agriculture of Polissya during 2015-2017, the Avatar-1 drug, the Protected Area, was tested for the purpose of protecting planting material and fruit-bearing hops from illness. Stopped at the most effective norms of the drug - 10 and $20 \mathrm{ml} / 10$ liters of water. Influence of biofungicide on yield and formation of hops seedlings and their damage by unreal powdery mildew were studied according to the method of Trybel S.O. (2001) by way of soaking the cuttings in the working solution [9]. For the standard used chemical registered fungicide systemic action Ridomil Gold MZ, inc. with the active substance metalaxyl-M, $40 \mathrm{~g} / \mathrm{kg}+$ mancozeb, $640 \mathrm{~g} / \mathrm{kg}$. In the control version cuttings of hops soaked with pure water [9, 10]. Fruit plants against pseudoperonosporosis were sprayed with a tractor fan sprayer OPV-2000. Standards for the cost of Avatar-1. The protection at that was $0.4-0.8 \mathrm{I} / \mathrm{ha}$, respectively, and Ridomil Gold MC, inc. - $2.5 \mathrm{~kg} /$ ha. Determination - acids in the cones of hops were carried out in accordance with DSTU 4099: 2009 Hops. Sampling rules and test methods [11].

Research results. It was established that soaking of husk cuttings with an exposition of 3 hours. in an aqueous solution of biofungicide Avatar-1, p. Protecting with concentrations of 10 and $20 \mathrm{ml}$ of the preparation for 10 liters of water, according to the options before landing in the field school ensured their survivability of $65.5-69.0 \%$, which is $3.0-6,5 \%$ more than in the control (Table 1 ).

1. Efficiency of application of biofungitsidy Avatar-1, p. Protection for soaking cuttings for the output of hop seedlings

\begin{tabular}{|c|c|c|c|c|}
\hline Options & $\begin{array}{c}\text { Placed } \\
\text { cuttings, pc. }\end{array}$ & $\begin{array}{c}\text { Grown up } \\
\text { seedlings, pcs. }\end{array}$ & Liveliness, \% & $\begin{array}{c}+/- \\
\text { to control }\end{array}$ \\
\hline $\begin{array}{c}\text { Control - soaking the cuttings of hops in } \\
\text { water }\end{array}$ & 200 & 125 & 62,5 & \\
\hline $\begin{array}{c}\text { Standard - Ridomil Gold MC, inc. - 25 g/10 } \\
\text { liters }\end{array}$ & 200 & 137 & 68,5 & $+6,0$ \\
\hline Avatar-1, p. Protect - 10 ml / 10 I & 200 & 131 & 65,5 & $+3,0$ \\
\hline Avatar-1, p. Protect - 20 ml / 10 I & 200 & 138 & 69,0 & $+6,5$ \\
\hline
\end{tabular}

In addition, the use of the drug had a positive effect on the process of formation and yield of standard saplings (Table 2).

2. Influence of Avatar-1, p. Protecting when soaking the cuttings before planting in the soil on the formation of standard seedlings of hops

\begin{tabular}{|c|c|c|c|c|c|c|c|}
\hline \multirow{3}{*}{ Options } & \multirow{3}{*}{$\begin{array}{l}\text { Seedlings, } \\
\text { pcs. }\end{array}$} & \multicolumn{4}{|c|}{ Includin } & \multirow{2}{*}{\multicolumn{2}{|c|}{$\begin{array}{c}\text { Damage of } \\
\text { seedlings by roo } \\
\text { rot }\end{array}$}} \\
\hline & & \multicolumn{2}{|c|}{$\begin{array}{l}\text { Standard- } \\
\text { them } \\
(1 \text { grade })\end{array}$} & \multicolumn{2}{|c|}{$\begin{array}{c}\text { Non-standard } \\
\text { ones } \\
\text { (2 degrees) } \\
\end{array}$} & & \\
\hline & & pc. & $\%$ & pc. & $\%$ & pc. & $\%$ \\
\hline $\begin{array}{l}\text { Control - soaking the cuttings of hops } \\
\text { in water }\end{array}$ & 125 & 81 & 67,5 & 39 & 32,5 & 7 & 6,0 \\
\hline $\begin{array}{c}\text { Standard - Ridomil Gold MC, inc. - } 25 \\
\text { g/ } 10 \text { I }\end{array}$ & 137 & 121 & 88,3 & 16 & 11,7 & 2 & 1,5 \\
\hline Avatar-1, p. Protect - $10 \mathrm{ml} / 10 \mathrm{I}$ & 131 & 100 & 76,3 & 31 & 23,7 & 5 & 4,0 \\
\hline Avatar-1, p. Protect - $20 \mathrm{ml} / 10$ I & 138 & 115 & 83,3 & 23 & 16,7 & 5 & 3,7 \\
\hline
\end{tabular}


After digging the seedlings, there was a significant difference between soaked hopper cuttings in the solution of the bio-fungicide Avatar-1, p. Protection and control plants. In experimental variants the number of main and auxiliary roots was 2-3 times greater than control, they were $10-20 \mathrm{~cm}$ longer and better developed.

3. Influence of Avatar-1, p. Protection against damage to plants of hops by unreal powdery mildew when soaking seedlings before landing in the soil.

\begin{tabular}{|l|c|c|c|c|}
\hline \multirow{2}{*}{ Opportunities for the experiment } & \multicolumn{4}{l}{ Frustration on ... day after the stairs, \% } \\
\cline { 2 - 5 } & 10 & 15 & 20 & 25 \\
\hline Control - soaking the cuttings of hops in water & 13,2 & 18,6 & 36,4 & 56,2 \\
\hline Standard - Ridomil Gold MC, v.g. - 25 g / 10 I & 1,8 & 2,5 & 8,7 & 17,5 \\
\hline Avatar-1, p. Protect - 10 ml / 10 I & 5,4 & 5,9 & 17,4 & 25,9 \\
\hline Avatar-1, p. Protect - 20 ml / 10 I & 2,1 & 3,0 & 10,2 & 19,4 \\
\hline
\end{tabular}

The results of the effectiveness of the biofungitsidy Avatar-1, p. The protection in the treatment of hops from diseases of diseases is given in Table 3, from which it is clear that the highest development of pseudoperonosporosis on plants after 25 days after the stains was observed in the control variant, in which seedlings of hops soaked in pure water $(56.2 \%)$. In variants, where seedlings of hops soaked in different norms of biofungitsidy Avatar-1, p. Protection, plant damage by disease on the 25th day after the stairs amounted to $19.4-25.9 \%$, respectively, which is 30.3 and $36.8 \%$ less than control.

The use of the drug Avatar-1, p. Protecting on fruit-bearing hops, after cutting the hams moths (Table 4) allows to reduce the number of colossal shoots on hopper stairs (primary infection of the disease) compared with the control. Thus, in the control version of the 10th day after the emergence of seedlings, the number of colossal shoots was 29 pcs. / 10 hops, whereas after the use of Avatar-1, p. Protection with norms of 10 and $20 \mathrm{ml}$ per 10 liters of water coloscopic shoots was 10-15 pcs. / 10 hop plants, and in the standard there were 8 pcs.

4. Impact of Avatar-1, p. Protecting the damage of hops plants by unreal powdery mildew during the processing of hop moths after cutting.

\begin{tabular}{|c|c|c|c|c|}
\hline \multirow{2}{*}{ Opportunities for the experiment } & \multicolumn{4}{|c|}{$\begin{array}{l}\text { Number of colossal shoots of hop rains on ... day of } \\
\text { counting, pcs. for } 10 \text { bushes. }\end{array}$} \\
\hline & 3 & 5 & 7 & \\
\hline Control - soaking the cuttings of hops in water & 6 & 10 & 22 & \\
\hline Standard - Ridomil Gold MC, v.g. - 25 g / 10 I & 0 & 2 & 5 & \\
\hline Avatar-1, p. Protect - $10 \mathrm{ml} / 10 \mathrm{I}$ & 0 & 3 & 10 & \\
\hline Avatar-1, p. Protect - $20 \mathrm{ml} / 10 \mathrm{I}$ & 0 & 3 & 8 & \\
\hline
\end{tabular}

Application of different standards of the drug (0,4-0,8 I / ha) Avatar-1, p. Protection against fungal plants of hops from unreal powdery mildew (Table 5) provided effectiveness against pseudoperonosporosis on hop leaves in the range of $74,2-74.4 \%$; and on cones - $62.5-65.6 \%$ compared with control. 
5. Results of the effectiveness of Avatar-1, p. Protecting the protection of hops from pseudoperonosporosis.

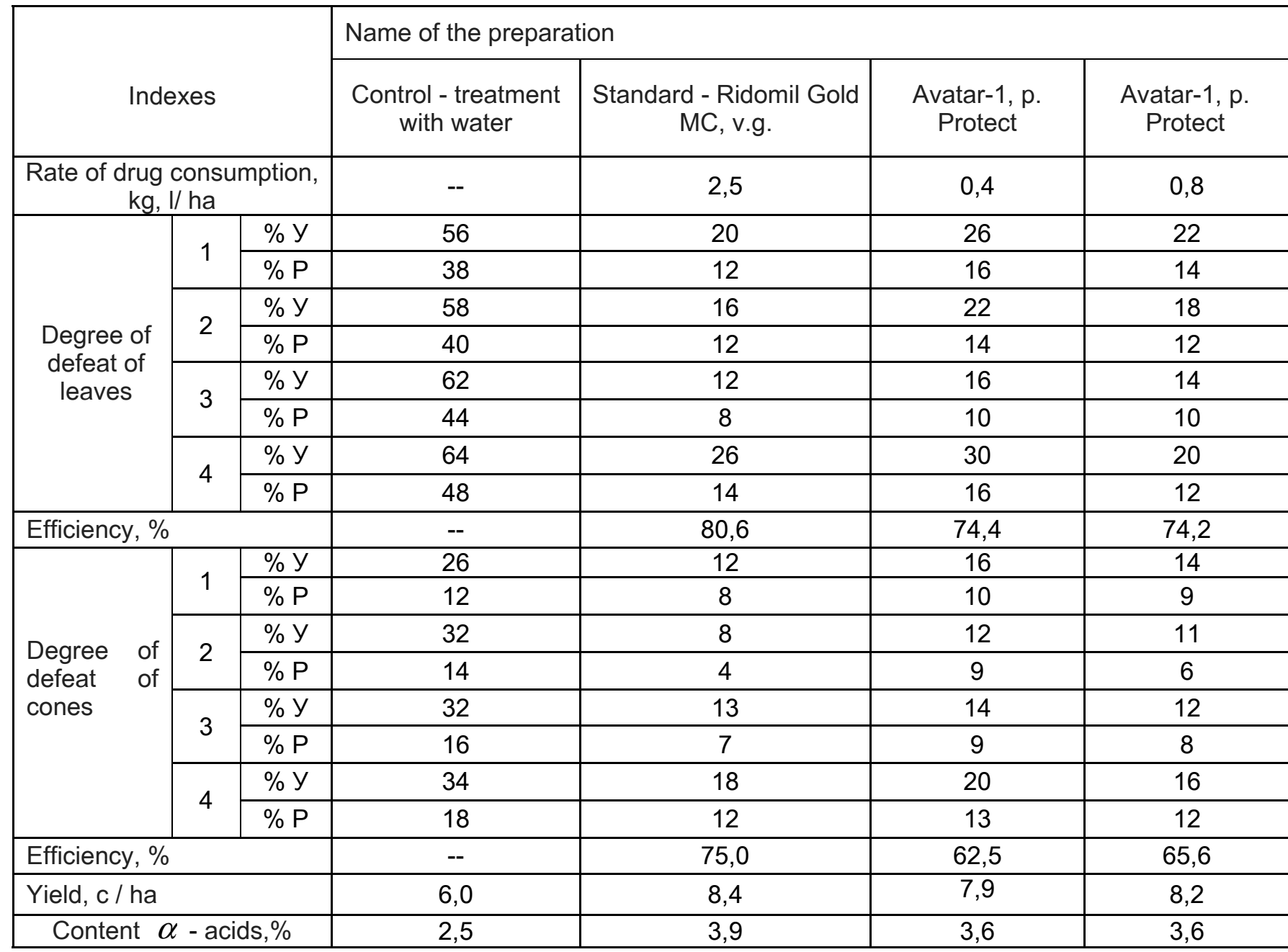

Note: \% Y - Percentage of plant infectious diseases

$\% \mathrm{P}$ - prevalence of illness in percentage

Also studied biochemical indicators of the quality of hops cones and yields on experimental sites. According to Table 5, yields in relation to controls increased by 1.9-2.2 centners per hectare and the content of acids by $1.1 \%$.

\section{Conclusions}

The conducted researches have determined that the use of the biofungitsidy Avatar- $1, \mathrm{p}$. Protection provides the healing of hop harvested by $3-6.5 \%$ higher than control, makes it possible to obtain $8.8-15.8 \%$ more than standard seedlings with well-developed main and auxiliary roots $2 \%$ reduces the infestation of planting material with root rot.

It was established that the use of this drug immediately after cutting the main rhizomes in the normal range of $10-20 \mathrm{ml}$ per 10 liters of water can significantly reduce the number of primary infection (colossal shoots), restraining the damage of seedlings pseudoperonosporozom in the period from the appearance of stairs to plant height 1,5-2, $0 \mathrm{~m}$. Allows you to cancel one spraying with fungicides, and to carry out spring work for the care of hops (hanging the wire, planting stems on the support). The effectiveness of a biofungicide for the protection of hops from pseudoperonosporosis is high and is $65.6-74.4 \%$, at a rate of consumption of $0.4-0.8 \mathrm{I} / \mathrm{ha}$.

The obtained results prove that it is expedient to include in the technological process of growing hop the operation of soaking the seedlings before planting in a solution of Avatar-1, p. Protect $(10-20 \mathrm{ml} / 10 \mathrm{I}$ of water) with an exposure of 3 hours. 


\section{Bibliography}

1. Wenger V., Savchenko Yu., Kovalev V. Lukashevich N., Wenger O., Yakubenko I. ... Rudik R. Tehnologiya viroshchuvannya ta zahistu hmelu vid shkidliv ih organismiv [Technology for the cultivation and protection of hops from harmful organisms]. Kyiv: Phoenix, 2011. 196 p. [in Ukrainian].

2. Boyarin V. (2006) Agate-25 Knaposivahzernovih. [Agate-25K on cereals]. Quarantine and plant protection. No7. P. 13-14. [in Ukrainian].

3. Volkogon V., Nadkernichna O., Kovalevskaya T., Tokmakova L. Mikrobnipreparati u zemlerobstvi.Teoriya i praktika:Monografia [Microbial drugs in agriculture. Theory and practice:Monograf]. (V. Volkogon ed.). (2006) Kyiv: Agrarian Science. 312 p. [in Ukrainian].

4. Wenger O. (2017) Zastosuvannya organichnogo dobriva Avatar-1p. Zahist $z$ fungicidnimi $v$ lastivvostyami $v$ nasadjennia hmelu [Application of organic fertilizer AVATAR-1, p., PROTECTION with fungicidal properties in hop plantings]. Agrarian. No. 21. P. 15-17. [in Ukrainian].

5. Onischuk D. (2015). Vpliv microelementnogo kompleksu Avatar-1p . Zahist na vrozhay nisttayakist hmele produkcii. [Influence of the microelement complex "Avatar-1" on yield and quality of hops]. Quarantine and plant protection. No. 7. P. 35-41. [in Ukrainian].

6. Wenger V., Yakubenko I., Fedorchuk N. (2013). Poshirenist korenevih gniley hmelu v hmelegospodarstvah Zhitomirskoi oblasti [Prevalence of root rot of hops in hop-keeping farms of Zhytomyr region]. Quarantine and plant protection. No.6. P. 19-21. [in Ukrainian].

7. Wenger V., Lapa O., Romanchuk V., Boroviy O., Lukashevich N., Wenger O. ... Kovalchuk S. Zahisth melu vid shkidnikiv hvorobta burianiv [Protection of hops from pests, diseases and weeds]. Kyiv: Univest Marketing LLC. 2004. 90 p. [in Ukrainian].

8. DSTU 4810-2: 2007 Sadivniymaterialhmelu.Sortoviisadivniyakosti. Tehnicni umovi. [Garden material of hop. varietal and gardening qualities]. Specifications. [in Ukrainian].

9. Trybel S., Sigareva D., Secun M., Ivashchenko O. Metodiki viprobuvannia i zastosuvannia pesticidiv. [Methods of testing and application of pesticides]. Kyiv: World. 2001. P. 448. [in Ukrainian].

10. Wenger V., Rudik R., Yakubenko I., Wenger O., Fedorchuk N. Lapa O., Zozulya O. Zahist hmelu za tehnologieu kompanii“Singenta”. [Protecting hops by Syngenta technology. Scientific methodical recommendations]. 2012. 15 p. [in Ukrainian].

11. Hops Sampling rules and testing methods DSTU 4099: 2009. Effective from 2011-07-01. Kyiv: Derzhspozhyvstandard Ukraine 2010. 32 p. (National Standard of Ukraine). [in Ukrainian]. 